Japan. J. Med. Sci. Biol., 40, 137-145, 1987.

\title{
CYTOGENETIC STUDIES ON BLOOD LYMPHOCYTES FROM PATIENTS WITH SCHISTOSOMA MANSONI
}

Esmail Kadhom SHUBBER and Hashim SALIH1

Department of Biochemistry, Faculty of Agriculture and Biology, P. O. Box 765, Baghdad, and 1Department of Bilharziasis, Endemic Disease Institute, Baghdad, Iraq

(Received September 7, 1987. Accepted March 2, 1988)

SUMMARY: Chromosomal aberrations and sister chromatid exchange (SCE) frequencies were studied in peripheral blood lymphocytes from 10 patients with Schistosoma mansoni prior to initiation of chemotherapy. The mean frequencies of chromatid and chromosome breaks for the patients were 1.80 and $2.30 \%$, respectively, which were significantly higher $(\mathrm{P}<0.01)$ than the means 0.35 and $0.30 \%$, scored for 20 healthy controls. Significant increase in the mean frequency of SCEs in the patients (9.1 $\pm 0.5 \mathrm{SCE} / \mathrm{cell})$ was noticeable when compared with the controls (6.2 $\pm 0.1 \mathrm{SCEs} / \mathrm{cell})$. Reductions in the lymphocyte divisions and replications in the patients were also observed. These results indicate that infection with $S$. mansoni could have in vivo mutagenic effects on human chromosomes.

\section{INTRODUCTION}

Since the development of convenient methods for culturing peripheral blood lymphocytes in 1960s, the study of human chromosomes has rapidly been advanced. Analyses of chromosomal aberrations (CA) and sister chromatid exchanges (SCEs) are generally documented as sensitive biological tests for the detection of environmental and industrial mutagens in man (1-3). Significantly high frequencies of CA and SCEs have been recognized in syndromes associated with a high incidence of cancer such as Blooms syndrom (4) and Fanconi's anemia (5). Furthermore, it is well known that infectious diseases may cause damage to human chromosomes (6). High frequencies of CA and/or SCEs have been described 
in lymphocytes from patients with viral hepatitis (6) or schistosomiasis hematobium (7).

Shistosomiasis is a disease of serious public health and socioeconomic importance in 74 developing countries. It affects more than 200 million individuals in those countries with sever manifestation at ages between 10 and 30 years (8). This disease has been associated with cancer and this association is most prevalent between Schistosoma hematobium and bladder cancer (9). Association between other human infectious schistosome species, such as $S$. mansoni and $S$. japonicum, and liver cancer was also reported $(10,11)$.

Cytogenetic analyses for urethelial cells collected from patients with schistosomiasis hematobium showed an increased frequency of micronuclei. This suggests that such a type of infection may cause a release of the mutagen in the plasma and urine (12). Recently, we reported that the infection with $S$. hematobium could increase SCEs in the blood lymphocytes (7).

This paper reports the results of CA and SCE analyses of blood lymphocytes from individuals infected with $S$. mansoni.

\section{MATERIALS AND METHODS}

Population studied: Among many Egyptian workers living in Iraq now, 30 individual males were selected as they had lived in endemic areas of Schistosoma mansoni in Egypt. Stool examinations showed that 10 of these workers were infected with $S$. mansoni as diagnosed by presence of viable eggs from which the miracidia were hatched out (13), although no other infectious diseases could be detected. Those patients were referred to the Endemic Disease Institute in Baghdad for treatment. The remaining 20 individuals were healthy and treated as controls. The patients and the controls were living under similar socioeconomic conditions and not involved in smoking, alcoholism or medication for the last 3 years before blood was withdrawn. Blood samples were collected prior to the initiation of chemotherapy.

Cytogenetic analysis: Blood lymphocytes were cultured in RPMI-1640 medium to assay for CA, SCE, mitotic (MI) and replicative indices (RI) under optimum conditions $(14,15)$. Two cultures were initiated on the blood sample from each individual. Cultures from controls and test subjects were made simultaneously. Briefly, $0.5 \mathrm{ml}$ of heparinized blood was inoculated in $4.5 \mathrm{ml}$ of the medium containing heat-inactivated fetal calf serum in 10\%, PHA (Pharmacia) in $2 \mu \mathrm{g} / \mathrm{ml}$ and BUDR in $10 \mu \mathrm{g} / \mathrm{ml}$. The cultures were kept in the dark at $37 \mathrm{C}$ for 68 hr. Colchicine (Houde, France) was added at a concentration of $0.1 \mathrm{mg} / \mathrm{ml} 4 \mathrm{hr}$ before harvest. The cells were treated with $0.075 \mathrm{M} \mathrm{KCL}$, fixed with methanol: 
acetic acid (3:1 v/v) and spread on slides. Air-dried slides were then stained in a $2 \%$ Giemsa solution. The mitotic index was counted as a ratio of mitoses to interphase nuclei in at least 500 cells. Identical slides were stained in a 4,6-diamino-2phenylindol (DAPI) solution (16) and mounted with an alkaline buffer $(\mathrm{pH}=11.0)$. The chromosomal aberrations were counted in 100 first metaphases; the SCEs were scored in at least 40 well-spreaded second metaphases. The replicative index was analyzed in 100 consecutive metaphases cells as percentage of first, second and third cell divisions in the presence of BUDR (17).

Statistical analysis: The data were analyzed statistically by Student's t-test.

\section{RESULTS}

Chromosomal analyses were performed on 10 patients with $S$. mansoni and 20 healthy individulas at mean ages $( \pm \mathrm{SD}$ ) of $26 \pm 10.9$ and $31.1 \pm 10.6$ years, respectively. A total of 3,000 first metaphase cells were analyzed for chromosomal aberrations.

The most frequent aberrations found were chromatid and chromosome breaks. Other types of aberrations such as acentric ring and dicentric were rarely seen. Thus comparison between the two groups was limited to the most frequent types of aberrations (Tables I and II). Only six controls showed chromosomal aberrations in their lymphocytes, although four of them were above the age of 40 years. The frequencies of chromatid and chromosome breaks were 0.35 and $0.30 \%$, respectively, with a total of $0.65 \%$. On the other hand, all patients were found to carry chromatid and chromosome breaks with frequencies of 1.80 and $2.30 \%$, respectively. Their total aberration frequency was $4.1 \%$. This was significantly higher $(\mathrm{P}<0.01)$ than that of the controls. However, these patients displayed no significant relationship between the frequency of aberrations and the age or the duration of infection DI (DI is the period between first appearance of S. mansoni eggs in the patient's stool to blood withdrawn for cytogenetic analysis).

The spontaneous frequency of SCEs in blood lymphocytes from controls was

age-dependent (Table I). The SCE means for the individuals aged 20-29 years were 5.8 \pm 0.3 SCEs/cell and for those aged 40-50 years or above were 7.0 \pm 1.3 SCEs/cell. The difference between the two groups was significant $(P<0.05)$. The incidence of SCEs in the lymphocytes from the patients is presented in Table II. Their mean frequency was 9.1 $\pm 0.5 \mathrm{SCEs} /$ cell (range, 7.5-12.8 SCEs/cell). This was significantly higher $(\mathrm{P}<0.01)$ than that of the controls, $6.2 \pm 0.1 \mathrm{SCEs} / \mathrm{cell}$ (range 3.9-7.2 SCEs/cell). 
Table I. Cytogenetic analysis of blood lymphocytes from healthy individuals (controls)

\begin{tabular}{|c|c|c|c|c|c|c|}
\hline \multirow{2}{*}{\multicolumn{2}{|c|}{ No. $\begin{array}{c}\text { Age } \\
\text { (year) }\end{array}$}} & \multicolumn{2}{|c|}{$\begin{array}{l}\text { Chromosome aberrations } \\
\text { per } 100 \text { cells }\end{array}$} & \multirow[t]{2}{*}{$\begin{array}{l}\text { SCEs/cell } \\
\pm \mathrm{SEM}\end{array}$} & \multirow{2}{*}{$\begin{array}{l}\text { Mitotic } \\
\text { index } \\
\text { (MI) }\end{array}$} & \multirow{2}{*}{$\begin{array}{l}\text { Repli- } \\
\text { cative } \\
\text { index } \\
\text { (RI) }\end{array}$} \\
\hline & & Ct. Br. & Cs. Br. & & & \\
\hline 1 & 17 & 0 & 0 & $5.5 \pm 0.5$ & 7.7 & 1.93 \\
\hline 2 & 18 & 0 & 0 & $6.9 \pm 0.1$ & 4.8 & 1.83 \\
\hline 3 & 19 & 1 & 0 & $3.9 \pm 0.1$ & 4.5 & 1.70 \\
\hline 4 & 22 & 0 & 0 & $4.8 \pm 0.8$ & 10.0 & 1.68 \\
\hline 5 & 22 & 0 & 0 & $6.8 \pm 0.3$ & 4.0 & 1.75 \\
\hline 6 & 24 & 0 & 0 & $6.7 \pm 0.3$ & 6.0 & 1.76 \\
\hline 7 & 25 & 0 & 0 & $6.5 \pm 0.7$ & 4.3 & 1.84 \\
\hline 8 & 26 & 0 & 0 & $6.1 \pm 0.3$ & 5.0 & 1.85 \\
\hline 9 & 29 & 0 & 0 & $5.5 \pm 0.7$ & 4.7 & 1.48 \\
\hline 10 & 30 & 1 & 1 & $7.0 \pm 0.2$ & 5.0 & 1.65 \\
\hline 11 & 30 & 0 & 0 & $6.6 \pm 0.4$ & 7.4 & 1.75 \\
\hline 12 & 32 & 0 & 0 & $5.9 \pm 0.5$ & 6.1 & 1.46 \\
\hline 13 & 32 & 0 & 0 & $6.4 \pm 0.2$ & 7.2 & 1.96 \\
\hline 14 & 32 & 0 & 0 & $5.6 \pm 0.1$ & 1.5 & 1.65 \\
\hline 15 & 33 & 0 & 0 & $7.2 \pm 0.5$ & 5.8 & 1.64 \\
\hline 16 & 39 & 0 & 0 & $6.5 \pm 0.7$ & 5.7 & 1.65 \\
\hline 17 & 41 & 1 & 0 & $7.0 \pm 0.8$ & 4.0 & 1.45 \\
\hline 18 & 47 & 1 & 1 & $6.9 \pm 1.0$ & 5.6 & 1.49 \\
\hline 19 & 52 & 1 & 2 & $7.1 \pm 0.3$ & 3.8 & 1.40 \\
\hline 20 & 53 & 2 & 2 & $7.0 \pm 0.7$ & 4.0 & 1.35 \\
\hline \multicolumn{2}{|c|}{ Mean 31.1} & 0.35 & 0.30 & $6.2 \pm 0.1$ & $5.3 \pm 0.4$ & $1.66 \pm 0.03$ \\
\hline
\end{tabular}

Ct. Br. : Chromatid breaks; Cs. Br. : Chromosome breaks.

The infection with $S$. mansoni also caused a reduction in the lymphocyte division (MI) to about $60 \%$ of the controls. Cellular replication was also affected. The means of the RI were $1.66 \pm 0.03$ and $1.32 \pm 0.03$ for the controls and the patients, respectively (Tables I and II). This difference was significant at the level of $5 \%$ by Student's t-test. 
Table II. Cytogenetic analysis of blood lymphocytes from patients with $S$. mansoni

\begin{tabular}{|c|c|c|c|c|c|c|c|}
\hline \multirow{2}{*}{\multicolumn{2}{|c|}{ No. $\begin{array}{c}\text { Age } \\
\text { (year) }\end{array}$}} & \multirow{2}{*}{$\begin{array}{l}\text { Dura- } \\
\text { tion* } \\
\text { of infe- } \\
\text { ction } \\
\text { (year) }\end{array}$} & \multicolumn{2}{|c|}{$\begin{array}{l}\text { Chromosome } \\
\text { aberrations } \\
\text { per } 100 \text { cells }\end{array}$} & \multirow[t]{2}{*}{$\begin{array}{l}\text { SCEs/cell } \\
\pm \mathrm{SEM}\end{array}$} & \multirow{2}{*}{$\begin{array}{l}\text { Mito- } \\
\text { tic } \\
\text { index } \\
\text { (MI) }\end{array}$} & \multirow{2}{*}{$\begin{array}{l}\text { Repli- } \\
\text { cative } \\
\text { index } \\
(\mathrm{RI})\end{array}$} \\
\hline & & & Ct. Br. & Cs. Br. & & & \\
\hline 1 & 17 & 3 & 1 & 2 & $7.6 \pm 0.9$ & 3.6 & 1.47 \\
\hline 2 & 19 & 4 & 3 & 5 & $7.9 \pm 1.1$ & 2.8 & 1.36 \\
\hline 3 & 21 & 5 & 1 & 1 & $7.5 \pm 1.0$ & 3.4 & 1.30 \\
\hline 4 & 21 & 7 & 2 & 3 & $10.3 \pm 1.5$ & 2.1 & 1.19 \\
\hline 5 & 22 & 6 & 1 & 1 & $9.6 \pm 1.0$ & 2.7 & 1.27 \\
\hline 6 & 24 & 5 & 2 & 1 & $7.5 \pm 1.0$ & 4.0 & 1.50 \\
\hline 7 & 24 & 6 & 3 & 2 & $9.7 \pm 1.2$ & 4.7 & 1.39 \\
\hline 8 & 30 & 7 & 2 & 3 & $8.8 \pm 1.4$ & 3.5 & 1.35 \\
\hline 9 & 31 & 7 & 2 & 1 & $9.9 \pm 1.1$ & 1.6 & 1.25 \\
\hline 10 & 55 & 10 & 1 & 4 & $12.8 \pm 1.0$ & 4.0 & 1.20 \\
\hline \multicolumn{2}{|c|}{ Mean 26.4} & 6 & 1.80 & 2.30 & $9.1 \pm 0.5$ & $.2 \pm 0.2$ & $32 \pm 0.03$ \\
\hline
\end{tabular}

*Period between first appearance of $S$. mansoni eggs in the patients stool and blood withdrawn for cytogenetic analysis. Ct. Br. : Chromatid breaks; Cs. Br. : Chromosome breaks.

\section{DISCUSSION}

The increase in the spontaneous frequencies of chromatid-, chromosome breaks and SCEs in cells from aged individuals are in agreement with those observed by other investigators $(2,18,19)$. However, no evidence has been reported to show that spontaneous SCE frequencies are age-dependent $(20,21)$. These discrepancies may be due to variations in culture conditions, particularly the concentration of BUDR, and cell population (15).

Recovery from schistosomiasis was successfully achieved after 3 months of treatment with a single dose of Bilitricide (Praziquantel). Fortunately, five recovered individuals (those who could be followed up) showed significantly lower $(\mathrm{P}<0.05)$ mean values of $\mathrm{CA}(3.2 \%)$ and SCE $(8.0 \pm 0.6 \mathrm{SCE} / \mathrm{cell})$ than the 
pretreatment levels $(\mathrm{CA}=5.2 \%$ and $10.1 \pm 0.7 \mathrm{SCE} /$ cell $)$. However, the controls exhibited stable values of $\mathrm{CA}(0.66 \%)$ and $\mathrm{SCE}(6.5 \pm 0.7 \mathrm{SCE} /$ cell $)$ during this period (3 months) (Shubber and Salih, unpublished data). Together with these findings, the results of the present study indicate that the infection with Schistosoma monsoni causes chromosomal mutation in the host cells.

The mechanisms involved in the increase of chromosomal aberrations and SCEs in human blood lymphocytes by infection with $S$. mansoni are unknown. Several possibilities would explain this phenomenon: (a) lymphocytes isolated from patients with $S$. mansoni were found to be twice more sensitive to the induction of chromosomal aberrations and SCEs by an antischistosomal drug, hycanthone, and ultraviolet light (Shubber, unpublished data). This might suggest that schistosome infection can sensitize the host cells to chemical and physical mutagens; (b) the presence of schistosomes in the host blood may change the efficiency of cells for BUDR uptake and/or incorporation in the cellular DNA; (c) the possible role of the immunization process in changing the populations of $\mathrm{T}$ lymphocytes can not be excluded; and finally (d) it is suggested that infection with $S$. hematobium could increase the frequency of SCE (7) and may cause release of a mutagen(s) in the body fluids which increased the frequency of micronuclei in the urethelial cells (12). Similar association between the infection with $S$. mansoni and the release of mutagens may exist.

The reason for the variability in the mean frequencies of chromosomal aberrations and SCEs for the patients with S. manosoni is unknown; however, many factors such as disease duration, tensity of infection, severity, and patient's cellular immunity could be implicated in chromosomal aberrations and SCE elevation in this type of infection. Host-parasite relationship studies for $S$. mansoni infection have indicated the existance of parasite toxins circulating in the blood that affect the host immunity (22). Immunosuppressive agent which purified from the schistosomula of $S$. mansoni was found to act preferentially on Tlymphocytes, inhibiting their proliferation (23). Thus these observations may explain the cause of reduction in the levels of MI and RI (Table II).

Cytogenetic effects of $S$. mansoni on the host lymphocytes were compared with those induced by infection with $S$. hematobium (Table III) (7). Cells from patients with $S$. mansoni had SCEs higher than the controls by 2.9. However, this level was significantly lower $(\mathrm{P}<0.05)$ than the corresponding difference in SCEs between patients with $S$. hematobium and the control (by 4.3). Furthermore, significant differences in the ranges of SCEs and the reduction of cellular division between the two patient groups were also noticed (Table III). These variations may 
Table III. Cytogenetic analysis of blood lymphocytes from healthy individuals and patients with schistosomiasis

\begin{tabular}{lllll}
\hline & $\begin{array}{l}\text { Healthy } \\
\text { individuals }\end{array}$ & $\begin{array}{l}\text { Patients } \\
\text { with S. } \\
\text { mansoni }\end{array}$ & $\begin{array}{l}\text { Healthy } \\
\text { individuals }\end{array}$ & $\begin{array}{l}\text { Patients } 1 \text { with } \\
\text { S. hematobium }\end{array}$ \\
(Present study) & & (Adapted from Shubber, 1987) \\
\hline $\begin{array}{l}\text { Number } \\
\begin{array}{c}\text { Mean age } \\
\text { (yr) }\end{array}\end{array}$ & 20 & 10 & 24 & 13 \\
$\begin{array}{c}\text { Mean } \\
\text { duration of } \\
\text { infection(yr) }\end{array}$ & - & 26.4 & 24.3 & 11.3 \\
$\begin{array}{c}\text { Mitotic } \\
\text { index }\end{array}$ & $5.3 \pm 0.4$ & $3.2 \pm 0.3^{*}$ & $5.0 \pm 0.6$ & $2.3 \pm 0.4^{* *}$ \\
$\begin{array}{c}\text { Replicative } \\
\text { index }\end{array}$ & $1.66 \pm 0.03$ & $1.32 \pm 0.03^{*}$ & $1.78 \pm 0.04$ & $1.31 \pm 0.03$ \\
$\begin{array}{c}\text { Sister } \\
\text { chromatid } \\
\text { exchanges/ } \\
\text { cell X } \pm \text { SEM }\end{array}$ & $6.2 \pm 0.1$ & $9.1 \pm 0.5^{*}$ & $6.6 \pm 0.2$ & $10.9 \pm 1.1$ \\
Range & $3.9-7.2$ & $7.5-12.8$ & $3.5-8.2$ & $7.0-21.0$ \\
\hline
\end{tabular}

(*) Statistically significant at level of $5 \%$ by Student's t-test.

$(* *)$ Highly significant at level of $1 \%$ by Student's t-test.

(1) Data adapted from Shubber, 1987, concerning male patients only.

be due to the differences in the host immune responses, duration of infections and/or the pathobiological effects between the two schistosome species $(24,25)$.

Schistosomiasis mansoni is a common disease in Egypt and other parts of Africa and also in Latin America $(22,26)$. However, this disease has been associated with follicular lymphoma of the spleen (27), hepatocellular and bile duct carcinoma $(10,28)$, colorectal cancer $(29)$, and with testicular tumor $(30)$. Abnormalities in the frequencies of chromosomal aberrations and SCEs have been suggested to be a defect in DNA repair mechanisms and a predisposing factor for the development of neoplasia (31-34). The data presented in this study indicate that infection with $S$. mansoni causes DNA damage in the host somatic cells which leads to the development of chromatid-, chromosome breaks, and SCEs. Further 
investigation of the increase in the frequencies of these chromosomal abnormalities and predisposition of schistosomiasis patients to malignancies is required.

\section{ACKNOWLEDGEMENTS}

We thank Dr. H. Auda and Dr. Z. S. Al-Hakkak, Scientific Research Council, for their helpful discussion, Mr. A. H. Khalil for statistical analysis and Mrs. N. J. Al-Zubaidy for typing the manuscript.

\section{REFERENCES}

1. Latt, S., Allen, J., Bloom, S., Carrano, A., Falk, F., Kram, D., Schneider, E., Schreck, R., Tice, R., Whitefield, B. and Wolff, S. (1981): Mutat. Res., 87, 1762.

2. Evans, H. J. (1986): In M. Sorsa and H. Norppa (eds.), Monitoring of Occupational Genotoxicants. pp.3-24, ARL, Inc., New York.

3. Shubber, E. K., Nada, S. M. and Al-Alaak, B. M. A. (1987): J. Biol. Sci. Res., in press.

4. Chaganti, R., Schonberg, S. and German, J. (1974): Proc. Natl. Acad. Sci., 71, 4508-4512.

5. Morimoto, K., Miura, K., Kaneko, T., Iijima, K., Sato, M. and Koizumi, A. (1984): In R. R. Tice and A. Hollander (eds.), Sister Chromatid Exchanges. pp.801-812. Plenum Press, New York, London.

6. Kurvink, K., Bloomfield, C. D. and Cervenka, J. (1978): Exptl. Cell Res., 113, 450-453.

7. Shubber, E. K. (1987): Mutat. Res., 180, 93-99.

8. World Health Magazine (1984): "Schistosomiasis". No. 50, April-June, 1-30.

9. El-Sebai, I. (1978): Urol. Res., 6, 633-636.

10. Cheever, A. W. (1978): J. Natl. Cancer Inst., 61, 13-17.

11. Nakashima, T., Okuda, K., Kojiro, M., Sakamoto, K., Kubo, Y. and Shimokawa, Y.(1975): Cancer, 36, 1483-1489.

12. Raafat, M., El-Gerzawi, S. and Stich, H. F. (1984): J. Egypt. Natl. Cancer Inst., 1, 63-73.

13. World Health Organization, Report (1983): Diagnostic Techniques in Schistosomiasis Control. WHO/Schisto./83.69 and PDP/83.3.

14. Crossen, P. E. (1982): In A. A. Sandberg (ed.), "Sister Chromatid Exchange". pp.175-194. ARL, Inc., New York.

15. Shubber, E. K. and Al-Alaak, B. M. A. (1986): Nucleus, 29, 92-98.

16. Lin, M. and Alfi, O. (1976): Chromosoma, 57, 129-135.

17. Lamberti, L., Bnzetto, P. B. and Ardito, G. (1983): Mutat. Res., 120, 193-199. 
18. Hedner, K., Hogstedt, B., Koling, A. M., Mark-Vendel, E., Strombeck, B. and Mitelman, F. (1982): Human Genet., 62, 305-309.

19. Soper, K. A., Stolley, P. D., Gallawy, S. M., Smith, J. G., Nichols, W. W. and Wolman, S.R. (1984): Mutat. Res., 129, 77-88.

20. Morgan, W. F. and Crossen, P. E. (1977): Mutat. Res., 42, 305-312.

21. Carrano, A. V. and Moore, D. H. (1982): In J. Heddle (ed.), New Horizons in Genetic Toxicology. pp.268-304. Academic Press, New York.

22. World Health Organization, Memorada (1974): Bull. Wld Hlth Org., 51, 553594.

23. Mazingue, C., Stadler, B. M., Quatannens, B., Capron, A. and Weck De A. (1986): Int. Arch. Allergy Appl. Immunol., 80, 347-354.

24. Gilles, H. M. (1982): In P. Jordan and G. Webbe (eds.), Schistosomiasis Epidemiology, Treatments and Controls. pp.79-104. William Heinemann Med. Books, Ltd., London.

25. Prata, A. (1982): In P. Jordan and G. Webbe (eds.), Schistosomiasis Epidemiology, Treatments and Controls. pp.105-127. William Heineman Med. Books, Ltd., London.

26. Abdel-Salam, E., Abdel-Khalik, A., Abdel-Meguid, A., Barakat, W. and Mahmoud, A. A. (1986): Tissue antigens, 27, 142-146.

27. Andrade, Z. M. and Abreu, W. N. (1971): Amer. J. Trop. Med. Hyg., 20, $237-$ 243.

28. Greenwald, E. D., Greenwald, E. S. and Brenner, S. M. (1981): N. Y. State J. Med., 81, 324-326.

29. Earnshaw, P., Busutlil, A. and Ferguson, A. (1982): Cancer Res., 83, 31-44.

30. Bambirra, E. A., Andrade, J. S., Bamberg, A., Souza, E. A. C., Mitidiero, C. E. A. and Souza, A. F. (1986): Amer. J. Trop. Med. Hyg., 34, 791-792.

31. Preston, R. J. (1983): In T. Ishihara and M. S. Sasaki (eds.), Radiation Induced Chromosome Damage in Man. pp.111-126. ARL, Inc., New York.

32. Swift, M. (1977): In J. J. Mulvihill, R. W. Miller and J. E. Fraumeni (eds.), Genetics of Human Cancer. pp.200-215. Raven Press, New York.

33. Burgdorf, W., Kurvink, K. and Cervinka, J. (1977): J. Med. Genet., 14, 256257.

34. Thacker, J. and Cox, R. (1983): In T. Ishihara and M. S. Sasaki (eds.), Radiation Induced Chromosome Damage in Man. pp.235-275. ARL, Inc., New York. 